\title{
Economic Assessment of Brazilian Public Ports: Value-Based Management
}

\author{
Erivelto Fioresi de Sousa ${ }^{1}$ \\ erivelto.sousa@ifes.edu.br | (10 0000-0002-0470-1926 \\ Francisco José Kliemann Neto ${ }^{1}$ \\ kliemann@producao.ufrgs.br| (1) 0000-0002-8881-9226 \\ Rafael Fontoura Andriotti ${ }^{1}$ \\ Andriotti.rafael@gmail.com | (DD 0000-0001-7180-2914 \\ Rodrigo Rech Campagnolo ${ }^{1}$ \\ Campagnolo.rodrigo@gmail.com | (D) 0000-0003-1799-6812
}

\begin{abstract}
Ports are among the main links of the international logistic chain and, consequently, an important element of economic development. Thus, this study aims to investigate the economic and financial results of Brazilian public ports by evaluating their ability to generate economic value. Therefore, we assessed the port authorities with traditional financial indicators as well as with Economic Value Added (EVA) indicators, aiming to assess companies' ability to create wealth for ports' capital investors. Findings indicate that, despite the satisfactory financial situation, such results are not due to the businesses' operation, but most likely due to governmental subsidies. Port authorities also showed inefficiency to remunerate the capital invested. The study contributes to the literature by shedding light on the discussion about the economic and financial management of public ports and the use of public resources in the port sector.
\end{abstract}

\section{KEYWORDS}

Port Management, EVA, port rentability, port performance

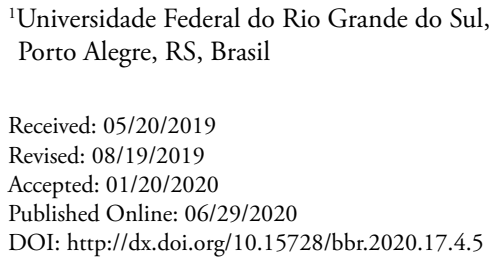

${ }^{1}$ Universidade Federal do Rio Grande do Sul, Porto Alegre, RS, Brasil

Received: 05/20/2019

Revised: 08/19/2019

Accepted: 01/20/2020

Published Online: 06/29/2020

DOI: http://dx.doi.org/10.15728/bbr.2020.17.4.5 


\section{INTRODUCTION}

This study aims to investigate the results of the economic and financial management of Brazilian public ports, based on the evaluation of their ability to generate economic value. According to Gomes, Dos Santos and Costa (2013) ports are an important part of economic development (Chang, Shin, \& Lee, 2014), once they are responsible for the import and export of goods destined for international trade.

Despite the important role played by ports in the economic context (Bottasso, Conti, Ferrari, $\&$ Tei, 2014), in Brazil, the need for investments in this sector is perceived as a matter of a deficit in infrastructure, which is evidenced by poorly equipped ports that are not able to meet maritime transportation requirements, as well as precarious facilities, and high handling costs (Alves \& Silva, 2015; Milan, Vieira, \& Gonçalves, 2014; Tovar \& Ferreira, 2006; Uderman, Rocha, \& Cavalcante, 2012).

Looking to reverse this situation, new legislation allows port management to be done as follows: infrastructure is provided by the public sector and the superstructure is provided by the private sector (Tovar \& Ferreira, 2006). This public/private model is known as a landlord port (GEIPOT, 2001). In the landlord model, the port authority acts as a general coordinator and manager of the space, with infrastructure investments from both public and private capital, whereas superstructure investments and provision of services are private (Britto et al., 2015; Vieira, Milan, Kliemann Neto, Rodrigues, \& Ramos, 2011).

Therefore, such an environment needs to be attractive to private investments with good economic and financial performance. In other words, the port sector's attractiveness to the private initiative is related to legal security and the perception of how the capital invested will be remunerated (Alves \& Silva, 2015). For the capital investor, one of the main ways to create value is the decision of where the capital will be invested (Brandáo, Bastian-Pinto, Gomes, \& Salgado, 2012), since the best decision must contemplate all the costs involved, including the cost of capital that remunerates investor's expectations (Silva \& Vieira, 2010).

To evaluate the ability of value generation and the return on the invested capital, we used the value-based management concept, which has guided companies to face increased competitiveness and demand for more efficient managerial actions (Martins, 2012). Thus, the Economic Value Added (EVA) concept was added in the analysis of the company's rentability, which is grounded in opportunity costs (Kitzberger \& Padoveze, 2004). The financial indicators show the solvency and ports' capacity to meet their obligations. However, regarding the creation of economic value and capital remuneration, the situation is different.

This study contributes to the discussion about the management of the public ports that are important agents of the economic development of a country and its competitiveness, focusing on decisions about public resource investment. The analysis of port financial results allows assessing their situation in relation to its competitors and determining its position in the market presenting the advantages and drawbacks of its activities in financial terms (Ignasiak-Szulc, Juscius, \& Bogatova, 2018). The literature shows that the competitiveness of the port sector depends on factors such as service quality, geographical location, port tariffs, and costs to be recovered (Bandara \& Nguyen, 2016; Fageda \& Gonzalez-Aregall, 2014; Notteboom, 2008). Thus, the financial performance may have an important role in the competitive positioning of the port.

Also, this study broadens the discussion about the performance of the port sector from economic and financial optics, according to trends observed around the world (Vaggelas, 2019). In the literature, we found research having mostly focused on the examination of operational parameters to assess the port performance (Beuren, Andriotti, Vieira, Ribeiro, \& Neto, 2018; 
Nguyen, Nghiem, \& Chang, 2018). Thus, in order to contribute to the literature, this paper investigates port performance from the perspective of economic and financial performance. However, before assessing ports for their economic and financial performance, it is necessary to highlight their strategic role and their ambivalence as a public company, administered both according to microeconomic guidelines, but also used as a public policy instrument (Rattner, 1984).

\section{THE BRAZILIAN PORT SECTOR}

The organization of the port sector is defined in Brazil's Federal Constitution. The Constitution states that the operation of ports is the Federal Government's competence, either directly or by delegation, which can occur through an authorization, concession, or permit. Additionally, it states that it is the Federal Government's competence to legislate about ports (Brazil, 1988).

Later, law 13.341/2016 granted such power to the Ministry of Transportation, Ports and Civil Aviation, today replaced by Ministry of Infrastructure, which is responsible to: a) formulate policies and guidelines for the development of the port sector and port facilities (maritime, river and lake) and the implementation and the evaluation of actions, programs and projects to support the development of infrastructure and superstructure and the facilities of maritime, river and lake ports; b) develop, coordinate and supervise national policies of the port sector and facilities of maritime, river and lake ports; c) participate in strategic planning, in the definition of implementation guidelines and the priorities for transportation investment programs; $d$ ) development of the infrastructure and superstructure of waterway ports and port facilities within its competence, promoting safety and efficiency of waterway transportation of cargo and passengers (Brazil, 2016).

Brazil gave the National Secretariat of Ports the responsibility to assist the Ministry in the coordination and supervision of the parts linked to the sector of ports and port facilities, by the Decree 9.000/2017 (Brazil, 2017). According to the National Secretariat of Ports, the Brazilian port sector has 37 public ports, 19 of which are administered by the Federal Government by means of the Companhia Docas, which acts as the Port Authority. The other 18 ports are managed by States or Municipalities through specific legal instrument.

Public ports may be (a) administered by the Federal Government through Port Authorities (called Companhias Docas) or (b) delegated to states or municipalities which, in turn, may manage these ports through public bodies or public companies created for this purpose. In all these kinds of ports, usually the port operations (handling and storage of goods) are performed by private companies, through port leasing contracts, which configure the landlord model (World Bank, 2001). However, some ports can still be found with other port management models such as the tool port (World Bank, 2001). Private Use Terminal (PUTs), in turn, are private terminals operated by private companies. These terminals are outside the polygon of the public ports and their implementation depends on public sector authorization.

Table 1 presents the Port Authorities managed by the Federal Government and the public ports administered by them. These Port Authorities will be the focus of the present study as they are public companies, created by law as stock companies, in which the Federal Government owns most of the voting shares (Brazil, 1967) presenting by legal obligation, the financial reports to consult. Since our research seeks to assess the economic and financial situation of port authorities, it is important to consider public companies, which present two opposing components: on one hand, with a macroeconomic focus, they are conceived as productivity units seeking efficiency 
BBR

17

442

and rentability, while on the other hand they are used as instruments of governmental policy (Rattner, 1984).

The ports of Laguna and Maceió are administered by Companhias Docas de São Paulo and Rio Grande do Norte, respectively, by delegation. Manaus' port, administered by Companhia Docas do Maranhão (CODOMAR), was excluded from the sample since only the financial reports for the years of 2011 and 2012 were available, for this reason it was not possible to perform the financial analyses consistently. Thus, the Table 2 presents the research sample.

Table 1

Port authorities and the ports under their administration.

\begin{tabular}{ll}
\hline \multicolumn{1}{c}{ Port Authority } & \multicolumn{1}{c}{ Port } \\
\hline Cia Docas do Espírito Santo - CODESA & Vitória, Barra do Riacho \\
Cia Docas de São Paulo - CODESP & Santos, Laguna \\
Cia Docas do Rio de Janeiro - CDRJ & Rio de janeiro, Itaguaí, Niterói and Angra dos Reis. \\
Cia Docas do Estado da Bahia - CODEBA & Salvador, Aratu and Ilhéus \\
Cia Docas do Rio Grande do Norte - CODERN & Natal, Maceió and Areia Branca \\
Cia Docas do Ceará - CDC & Fortaleza \\
Cia Docas do Pará - CDP & Belém, Santarém and Vila do Conde. \\
Cia Docas do Maranhão - CODOMAR & Manaus \\
\hline
\end{tabular}

Source: Elaborated by the authors.

Table 2

Port authorities of the sample used in the research

\begin{tabular}{ll}
\hline \multicolumn{1}{c}{ Port Authority } & \multicolumn{1}{c}{ Port } \\
\hline Cia Docas do Espírito Santo - CODESA & Vitória, Barra do Riacho \\
Cia Docas de Sáo Paulo - CODESP & Santos \\
Cia Docas do Rio de Janeiro - CDRJ & Rio de Janeiro, Itaguaí, Niterói and Angra dos Reis \\
Cia Docas do Estado da Bahia - CODEBA & Salvador, Aratu and Ilhéus \\
Cia Docas do Rio Grande do Norte - CODERN & Natal and Areia Branca \\
Cia Docas do Ceará - CDC & Fortaleza \\
Cia Docas do Pará - CDP & Belém, Santarém and Vila do Conde \\
\hline
\end{tabular}

Source: Elaborated by the authors.

Although wide and well spread along the coast, the Brazilian port sector has shown an infrastructure lag due to the low investments made by the public sector. Additionally, the high costs of cargo handling (Tovar \& Ferreira, 2006; Uderman et al., 2012) contributed to the sector's lack of competitivity. To revert this scenario and to modernize the port sector, the Brazilian Federal Government has made changes to legislation since the 1990s, initially through law 8.630/93 and, later, with law 12.815/2013 which repealed the former law to attract private investments in port operations (Britto et al., 2015; Fernandes, 2016; Pires, 2017; Rocha, Britto, \& Uderman, 2016; Tovar \& Ferreira, 2006). By means of these laws, the Federal Government sought to make the port sector more attractive from the private capital perspective, with legal security and the capability to repay the investments necessary to improve the system's competitiveness. 


\section{ECONOMIC AND FINANCIAL VALUE-BASED MANAGEMENT}

The analysis of the economic and financial situation of an organization is related to an assessment of the organization's capability to honor its financial (operational or capital) commitments with funders, since the financial situation is related to the cash flow management, and the economic situation is related to productivity and rentability (Brigham, Gapenski, \& Ehrhardt, 2001; Salazar, 2012). From the capital investor optics, rentability is one of the most important indicators since it shows the organization's ability to return the investments made (Martins, Diniz, \& Miranda, 2012).

In addition, according to Ignasiak-Szulc et al. (2018), the financial aspects of performance, as well as the advantages and drawbacks of the activities developed and accurate assesements of the competitiveness situation are based in the company's financial results.

Regarding the economic and financial assessments of companies, Araújo and Assaf Neto (2003) state that the traditional tools for performance measurement in financial management are losing ground to more refined techniques, moving from a focus on the assessment of profit and rentability to a focus on the creation of wealth for the investor. Thus, in value-based management the main objective of the organization is to maximize the economic value added to the investor (Araújo \& Assaf Neto, 2003; Neto, Araújo, \& Fregonesi, 2006).

Is this sense, the techniques to assess the rentability of an organization have been broadened, incorporating the concept of Economic Value Added (EVA), which is based on the opportunity cost (Kitzberger \& Padoveze, 2004). In other words, EVA is the net profit excluding the cost of equity capital, which represents the minimum remuneration demanded by the shareholders, considering the business risk level (Martins et al., 2012, p. 239). According to the authors, EVA is an indicator of a company's economic performance, presenting the company's ability to pay for its liabilities, to remunerate equity capital and to generate positive results, thus, indicating the company's economic and financial sustainability.

To Neto (2012), EVA is a value generation indicator of the operational performance of the company. Additionally, Brigham, Gapenski and Ehrhardt (2001) state that the EVA is an estimative of the actual economic return of the organization in the year, since it is the net profit excluding the cost of all the capital invested (equity and third-party). According to Martins, Diniz and Miranda (2012), the concept of EVA enables the correction of the accounting error of not considering shareholders' cost of capital as an expense in performance assessment. EVA addresses the need for the maximization of the company's value which is an important objective of financial management (Brigham et al., 2001).

Although EVA is a performance indicator related to the intrinsic market value of a company, it still finds limitations in the discussion about the appropriate cost of capital of a company, in addition to the fact that its calculation uses the accounting profit which can present limitations when used as a measure of value, since it is calculated based on accounting practices and choices (Aguiar, Pimentel, Rezende, \& Corrar, 2007; Sousa \& Galdi, 2016).

Finance literature has long discussed the informational relevance of traditional indicators and EVA. On the one hand research shows EVA as the most relevant economic and financial performance metric for companies (Lee \& Kim, 2009; Tan, Zhang, \& Ma, 2011; Tutino, 2011). On the other hand, other research papers pointed out traditional indicators as more information rich (Kim, 2006; Sharma \& Kumar, 2010). Most of the research that identified EVA as the most relevant metric has been conducted in developed economies (Girão, Machado, \& Callado, 2013). 
BBR

17

444

EVA is a measure of long-term performance, while traditional indicators assess short-term performance (Kim, 2006; Tan et al., 2011) being indicated for analysis in emerging and speculative markets, since speculators seek capital gains in the short term without considering the company's long-term expectations (Girão et al., 2013). In this sense, the economic and financial assessment can be more relevant when conducted jointly, using both the traditional indicators and EVA.

\section{MATERIAL AND METHODS}

Document research using financial reports and financial statements from Companhia Docas was carried out. Companhia Docas are the responsible entities from the Federal Government's direct administration in the ports analyzed. These companies were chosen because they are public companies constituted under joint-stock societies and, therefore they have the legal obligation of presenting financial statements and reports. Thus, we analyzed the financial statements and accounting reports of Companhias Docas available for public access in the companies' websites as shown in Table 3.

Table 3

Accounting Reports Analyzed in the Sample

\begin{tabular}{lcccccc}
\hline Port Authority & 2011 & 2012 & 2013 & 2014 & 2015 & 2016 \\
\hline Cia Docas do Espírito Santo - CODESA & $\mathrm{x}$ & $\mathrm{x}$ & $\mathrm{x}$ & $\mathrm{x}$ & $\mathrm{x}$ & $\mathrm{x}$ \\
Cia Docas de São Paulo - CODESP & $\mathrm{x}$ & $\mathrm{x}$ & $\mathrm{x}$ & $\mathrm{x}$ & $\mathrm{x}$ & $\mathrm{x}$ \\
Cia Docas do Rio de Janeiro - CDRJ & $\mathrm{x}$ & $\mathrm{x}$ & $\mathrm{x}$ & $\mathrm{x}$ & $\mathrm{x}$ & $\mathrm{x}$ \\
Cia Docas do Estado da Bahia - CODEBA & $\mathrm{x}$ & $\mathrm{x}$ & $\mathrm{x}$ & $\mathrm{x}$ & $\mathrm{x}$ & $\mathrm{x}$ \\
Cia Docas do Rio Grande do Norte - CODERN & $\mathrm{x}$ & $\mathrm{x}$ & $\mathrm{x}$ & - & $\mathrm{x}$ & $\mathrm{x}$ \\
Cia Docas do Ceará - CDC & $\mathrm{x}$ & $\mathrm{x}$ & $\mathrm{x}$ & $\mathrm{x}$ & $\mathrm{x}$ & $\mathrm{x}$ \\
Cia Docas do Pará - CDP & $\mathrm{x}$ & $\mathrm{x}$ & $\mathrm{x}$ & $\mathrm{x}$ & $\mathrm{x}$ & $\mathrm{x}$ \\
\hline
\end{tabular}

Source: Elaborated by the authors.

CODERN's accounting reports for the year 2014 were not available. In the first stage of the research, ports' main financial and economic indicators were analyzed, as seen in Table 4. Hence, we analyzed the solvency and profitability of the port authorities through the standard index method (Matarazzo, 2010) as calculated for the Brazilian port sector.

Regarding the value-based management analysis, we applied the Economic Value Added (EVA) concept which is based on a mathematical concept that uses the calculation basis of net operating profit after taxes, the invested capital and, as discount rate it uses the company's cost of capital. The company's cost of capital incorporates both equity capital and third-party capital. Therefore, to obtain the EVA, the following equation was applied:

$$
E V A=N O P A T-(C \% \times C T)
$$

where:

NOPAT $=$ Net Operating Profit After Taxes.

$\mathrm{C} \%=$ Percentage Cost of Capital (equity and third-party).

$\mathrm{CT}=$ Total Invested Capital, obtained by the sum of shareholders' equity and onerous liabilities (Neto, 2012). 
Table 4

Index for financial and economic analysis

Financial Situation Indicators

\begin{tabular}{|c|c|c|}
\hline Index & Formula & Indicates ... \\
\hline Current Ratio & $\frac{\text { Current Assets }}{\text { Current Liabilities }}$ & $\begin{array}{l}\text { The amount of the current assets for every } \\
\$ 1,00 \text { of the current liability. }\end{array}$ \\
\hline General Liquidity & $\frac{\text { Current Assets + Long-Term Asset }}{\text { Current Liabilities + Long-Term Liability }}$ & $\begin{array}{l}\text { The amount of receivables and assets in the } \\
\text { current assets and long-term assets that exist for } \\
\text { every } \$ 1,00 \text { of the company's total liability. }\end{array}$ \\
\hline $\begin{array}{l}\text { General } \\
\text { Indebtedness }\end{array}$ & $\frac{\text { Total Debt }}{\text { Total Asset }}$ & $\begin{array}{l}\text { The amount of money borrowed from third- } \\
\text { party capital for every } \$ 1,00 \text { of the total assets. }\end{array}$ \\
\hline Debt Composition & $\frac{\text { Current Liability }}{\text { Total Debt }}$ & $\begin{array}{l}\text { The percentage of short-term liabilities in } \\
\text { relation to the total liabilities }\end{array}$ \\
\hline $\begin{array}{l}\text { Need for Working } \\
\text { Capital }\end{array}$ & Current Assets - Current Liabilities & $\begin{array}{l}\text { The funds invested in current assets necessary } \\
\text { for the company to sustain its immediate } \\
\text { operating activities }\end{array}$ \\
\hline \multicolumn{3}{|c|}{ Economic Situation Indicators } \\
\hline Index & Formula & Indicates... \\
\hline Operating Margin & $\frac{\text { Operating Profit }}{\text { Net Sales }}$ & $\begin{array}{l}\text { The proportion of operating profit for every } \\
\$ 1,00 \text { sold. }\end{array}$ \\
\hline Net Margin & $\frac{\text { Net Profit }}{\text { Net Sales }}$ & The profit for every $\$ 1,00$ sold. \\
\hline Asset Turnover & $\frac{\text { Net Sales }}{\text { Total Assets }}$ & $\begin{array}{l}\text { The revenue sales for every } \$ 1,00 \text { of the total } \\
\text { investments. }\end{array}$ \\
\hline $\begin{array}{l}\text { Return on Assets } \\
\text { (ROA) }\end{array}$ & $\frac{\text { Net Operating Profit After Taxes }}{\text { Average Total Assets }}$ & $\begin{array}{l}\text { The operating profit for every } \$ 1,00 \text { of the total } \\
\text { investment. }\end{array}$ \\
\hline $\begin{array}{l}\text { Return on Equity } \\
\text { (ROE) }\end{array}$ & $\frac{\text { Net Income }}{\text { Shareholders' Equity }}$ & $\begin{array}{l}\text { The profitability of the company for every } \\
\$ 1,00 \text { of the shareholders' equity invested, in } \\
\text { average, in a year. }\end{array}$ \\
\hline
\end{tabular}

Source: Adapted from Martins (2012) and Matarazzo (2010).

The percentage cost of capital, which serves as the discount rate, is represented by the Weighted Average Cost of Capital (WACC) which depicts the average cost of equity capital and third-party capital used to finance the company's investments weighted by their share of the company's capital (Bruni \& Famá, 2003; Neto, Lima, \& Araújo, 2008).

To obtain the WACC, we employed a commonly used methodology found in the literature, which is presented in Equation 2. We followed the orientations provided by ANTAQ's Technical Note n. 17/2007-GPP which addresses modelling of feasibility studies for lease projects, and the Technical Note n. 25/2009-GPP, which updates the weighted average cost of capital for the port sectors. 


$$
W A C C=\frac{P L}{P+P L} * K e+\frac{P}{P+P L} * K d *(1-I R)
$$

where:

$\mathrm{Ke}=$ opportunity cost of equity capital;

$\frac{\mathrm{PL}}{\mathrm{P}+\mathrm{PL}}=$ equity capital ratio;

$\mathrm{Kd}=$ cost of debt;

$\frac{\mathrm{P}}{\mathrm{P}+\mathrm{PL}}=$ third-party (onerous) capital ratio $[\mathrm{P} / \mathrm{P}+\mathrm{PL}]$;

$\mathrm{P}, \mathrm{PL}=$ respectively, onerous liabilities and shareholders' equity;

IR = income tax and social contributions on net profit rate.

To calculate the opportunity cost of equity capital, which is the rate required by investors, literature has frequently presented the Capital Assets Pricing Model (CAPM). The calculation of CAPM considers the existence of a risk-free interest rate, an expected market return, as well as a business risk measure in relation to the market (Neto et al., 2008), represented by equation 3:

$$
K e=R f+(R m-R f) * \beta
$$

where:

$\mathrm{Ke}=$ equity cost of capital

$\mathrm{Rf}=$ risk-free rate

$\beta=$ investment risk compared to the market

$(\mathrm{Rm}-\mathrm{Rf})=$ Compensation for market risk

In Brazil's emerging market environment, some difficulties arise in determining the variables of the model when calculating the rate required by investors, for example, since the risk-free rate cannot "present any uncertainty to the compliance of any contractual obligation" (Neto et al., 2008, p. 76).

According to Neto et al. (2008), assessment models have adopted the interest rates paid for public securities as risk-free rates, which are impaired in the Brazilian market since these securities include a risk compensation, in addition to the great variability in the historical series of interest rates - Special Clearance and Escrow System (SELIC) - which demands the use of interest rates that represent a benchmark of the financial market. In this case, the Treasury Bonds issued by the Treasury Department of the United States Government are highlighted (Neto, 2012; Neto et al., 2008, p. 76).

Therefore, following ANTAQ's orientations, we used the interest rates paid by the American T-Bonds (Treasury Bonds) as risk-free rates. In the same line, the market return measured by S\&P500 (Standard \& Poor's Index Services) was used as market return index (ANTAQ, 2007).

Systematic risk measurement measured by the beta coefficient $(\beta)$ followed the reasoning behind previous variables and was obtained through benchmark. To that end, we used the unleveraged beta of the maritime industry in the American market which was leveraged based on the capital structures of Brazilian port authorities (ANTAQ, 2007).

To adjust the opportunity cost of equity capital to the uncertainties of the Brazilian market, we added a country risk measure to the CAPM model, which aims to represent the risk from the country's economy. This is calculated by the excess compensation paid by public bonds in relation to the similar bonds issued by the United States Treasury (Neto et al., 2008, p. 76). 
Additionally, according to ANTAQ's orientation, we added a regulation risk measure to the cost of equity capital, which may introduce a certain level of systematic risk to the company (ANTAQ, 2007). The so-called regulatory risk is understood as a specific risk component for companies that operate in regulated sectors and which can arise from changes to the legal structure, tariff updates, among other forms of limits and restrictions imposed by the Federal Government (Taffarel, Silva, \& Clemente, 2013). According to the Technical Note n. 25/2009 - GPP article 12 , the regulatory risk is set at 3\% per year (ANTAQ, 2009). Therefore, the calculation of CAPM followed Equation 4.

$$
K e=R f+(R m-R f) * \beta+R_{b r}+R_{r e g}
$$

where:

$\mathrm{R}_{\mathrm{br}}=$ compensation for country risk

$\mathrm{R}_{\mathrm{reg}}=$ regulatory risk

The cost of debt, on the other hand, also followed ANTAQ's guidelines and was measured based on the cost of the line of funding for investments on logistics and transportation infrastructure (Finem) of the National Bank for Economic and Social Development (BNDES) which has a specific segment for ports. Additionally, we considered Central Bank's SELIC rate, the basic interest rate of the Brazilian economy. Thus, the cost of debt was obtained by the weighted average cost of BNDES and SELIC by the weights $83.33 \%$ and $16.67 \%$, respectively. The weights follow the guidelines ANTAQ standards regarding the WACC update for lease project feasibility studies (ANTAQ, 2009).

\section{PRESENTATION AND ANALYSIS OF THE RESULTS}

As market benchmark, we used the standard index methodology (Matarazzo, 2010). According to the author, after the calculation of the companies' indices in the market, the indices are grouped and ranked in an increasing order and divided into deciles, where each decile represents the performance pattern of a group of market companies, as Chart 1 presents.

Chart 1

Concepts and scores attributed to the assessment indices

\begin{tabular}{|c|c|c|c|c|c|c|c|c|c|c|c|c|}
\hline Indicators & & Bottom & $\begin{array}{c}1^{\mathrm{o}} \\
\text { Decile }\end{array}$ & $\begin{array}{c}2^{\circ} \\
\text { Decile }\end{array}$ & $\begin{array}{c}3^{\circ} \\
\text { Decile }\end{array}$ & $\begin{array}{c}4^{\circ} \\
\text { Decile }\end{array}$ & $\begin{array}{c}5^{\circ} \\
\text { Decile }\end{array}$ & $\begin{array}{c}6^{\circ} \\
\text { Decile }\end{array}$ & $\begin{array}{c}7^{\circ} \\
\text { Decile }\end{array}$ & $\begin{array}{c}8^{\circ} \\
\text { Decile }\end{array}$ & $\begin{array}{c}90 \\
\text { Decile }\end{array}$ & Higher \\
\hline $\begin{array}{l}\text { General } \\
\text { Indebtedness }\end{array}$ & Concept & & Great & & & & Satisfactory & $\begin{array}{r}\text { Reaso } \\
\text { W }\end{array}$ & $\begin{array}{l}\text { nable/ } \\
\text { eak }\end{array}$ & Det & cient & Terrible \\
\hline $\begin{array}{l}\text { Need For } \\
\text { Working } \\
\text { Capital } \\
\text { Liquitidy }\end{array}$ & Score & 10 & 9 & 8 & 7 & 6 & 5 & 4 & 3 & 2 & 1 & 0 \\
\hline Margin & Concept & Terrible & \multicolumn{2}{|c|}{ Deficient } & \multicolumn{2}{|c|}{$\begin{array}{c}\text { Reasonable/ } \\
\text { Weak }\end{array}$} & Satisfactory & & Good & & \multicolumn{2}{|c|}{ Great } \\
\hline \multicolumn{13}{|l|}{ ROE } \\
\hline ROA & Score & 0 & 1 & 2 & 3 & 4 & 5 & 6 & 7 & 8 & 9 & 10 \\
\hline
\end{tabular}

Source: Adapted from Matarazzo (2010). 
BBR

17

448

Table 5 presents the standard indices for the indicators assessed in the sample, which served as basis for the analysis of the ports' sample.

Table 5

Standard indices of the port sector

\begin{tabular}{|c|c|c|c|c|c|c|c|c|c|}
\hline Indicators & $\begin{array}{c}1 \text { st } \\
\text { Decile }\end{array}$ & $\begin{array}{c}\text { 2nd } \\
\text { Decile }\end{array}$ & $\begin{array}{c}\text { 3rd } \\
\text { Decile }\end{array}$ & $\begin{array}{c}\text { 4th } \\
\text { Decile }\end{array}$ & $\begin{array}{c}5 \text { th } \\
\text { Decile }\end{array}$ & $\begin{array}{c}\text { 6th } \\
\text { Decile }\end{array}$ & $\begin{array}{c}7 \text { th } \\
\text { Decile }\end{array}$ & $\begin{array}{c}\text { 8th } \\
\text { Decile }\end{array}$ & $\begin{array}{c}\text { 9th } \\
\text { Decile }\end{array}$ \\
\hline Current Ratio & 0,17 & 0,45 & 0,73 & 0,92 & 1,20 & 1,73 & 2,01 & 2,36 & 4,09 \\
\hline $\begin{array}{l}\text { General } \\
\text { Liquidity }\end{array}$ & 0,55 & 1,00 & 1,56 & 2,19 & 2,28 & 2,60 & 3,15 & 3,44 & 4,34 \\
\hline $\begin{array}{l}\text { General } \\
\text { Indebtedness }\end{array}$ & $14,2 \%$ & $23,0 \%$ & $24,7 \%$ & $30,3 \%$ & $34,4 \%$ & $43,1 \%$ & $49,3 \%$ & $55,6 \%$ & $100,1 \%$ \\
\hline $\begin{array}{l}\text { Debt } \\
\text { composition }\end{array}$ & $17,2 \%$ & $21,4 \%$ & $24,4 \%$ & $30,8 \%$ & $39,1 \%$ & $49,2 \%$ & $63,0 \%$ & $79,3 \%$ & $88,1 \%$ \\
\hline $\begin{array}{l}\text { Need for } \\
\text { working capital } \\
\text { (in millions } \\
\text { of Reais) }\end{array}$ & -359.293 & -287.622 & -266.674 & -188.702 & -50.696 & -33.044 & -9.993 & -4.019 & 2.205 \\
\hline $\begin{array}{l}\text { Operating } \\
\text { margin }\end{array}$ & $-167,3 \%$ & $-64,5 \%$ & $-26,6 \%$ & $-8,9 \%$ & $-1,8 \%$ & $1,6 \%$ & $7,4 \%$ & $11,1 \%$ & $14,6 \%$ \\
\hline Net margin & $-146,9 \%$ & $-64,5 \%$ & $-38,7 \%$ & $-8,5 \%$ & $-1,8 \%$ & $1,0 \%$ & $5,8 \%$ & $8,7 \%$ & $11,3 \%$ \\
\hline Asset turnover & 0,08 & 0,12 & 0,17 & 0,22 & 0,24 & 0,26 & 0,27 & 0,28 & 0,31 \\
\hline ROA & $-10,8 \%$ & $-9,7 \%$ & $-5,9 \%$ & $-2,9 \%$ & $-0,5 \%$ & $0,2 \%$ & $1,6 \%$ & $2,5 \%$ & $3,4 \%$ \\
\hline ROE & $-14,0 \%$ & $-7,6 \%$ & $-3,6 \%$ & $-0,3 \%$ & $0,5 \%$ & $2,7 \%$ & $3,9 \%$ & $5,3 \%$ & $35,8 \%$ \\
\hline
\end{tabular}

Source: Elaborated by the authors.

Table 6 presents the financial and economic indicators of the Port Authorities analyzed in the period between 2011 and 2016.

Liquidity indicators of CODESA have undergone variations over the time, going from a below-satisfactory situation to a great situation. Nevertheless, CODESA's liquidity was consistent with the sector's average. Moreover, the need for working capital was negative, which indicates a surplus of financial resources on hand. Indebtedness was satisfactory on average, and it was mostly of the long-term type. Regarding rentability, findings show low attractiveness with high volatility, which was also identified when assessing the Return on Asset and the Return on Equity.

CDRJ's indebtedness is concerning, since entire assets are financed by third-party long-term capital and this is the most indebted authority of the sector. Nevertheless, we found that there is surplus in financial resources based on the need for working capital, in spite of presenting below average liquidity indicators when compared to the other port authorities. As to the rentability, findings do not show a satisfactory situation, rather we found negative returns. Return on equity capital is affected by the unsecured liabilities, when the shareholders' equity is negative. These indicators show an extremely risky economic and financial situation. 
Table 6

Financial and economic indicators of the Port Authorities sampled

\begin{tabular}{|c|c|c|c|c|c|c|c|c|c|c|}
\hline \multicolumn{2}{|c|}{ Indicator } & Period & CODESA & CDRJ & CODESP & CODEBA & CODERN & $\mathrm{CDP}$ & $\mathrm{CDC}$ & Average \\
\hline \multirow{30}{*}{ 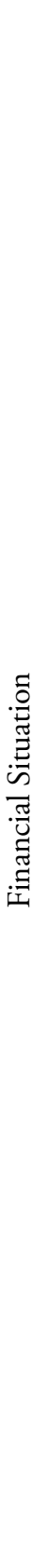 } & \multirow{5}{*}{ 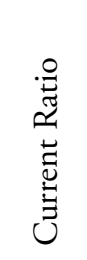 } & 2011 & 1,00 & 0,71 & 0,89 & 2,04 & 3,80 & 5,26 & 6,64 & 2,91 \\
\hline & & 2012 & 1,86 & 0,21 & 0,86 & 2,16 & 3,83 & 7,23 & 4,11 & 2,89 \\
\hline & & 2013 & 0,56 & 0,47 & 1,26 & 1,75 & 1,95 & 5,43 & 2,46 & 1,98 \\
\hline & & 2014 & 1,32 & 0,77 & 0,34 & 1,69 & - & 2,35 & 0,16 & 1,11 \\
\hline & & 2015 & 2,32 & 0,14 & 0,44 & 1,82 & 1,13 & 0,91 & 0,35 & 1,02 \\
\hline & \multirow{7}{*}{ 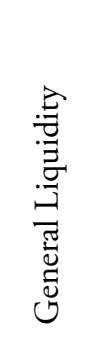 } & 2016 & 2,37 & 0,08 & 0,49 & 1,35 & 0,94 & 0,93 & 0,14 & 0,90 \\
\hline & & 2011 & 1,66 & 0,72 & 2,72 & 2,41 & 4,35 & 2,36 & 7,11 & 3,05 \\
\hline & & 2012 & 2,61 & 0,54 & 3,41 & 2,58 & 4,24 & 3,37 & 4,66 & 3,06 \\
\hline & & 2013 & 1,01 & 0,99 & 4,97 & 2,16 & 2,23 & 4,35 & 2,98 & 2,67 \\
\hline & & 2014 & 2,04 & 2,30 & 3,78 & 2,15 & - & 3,03 & 0,27 & 2,26 \\
\hline & & 2015 & 3,45 & 0,79 & 4,22 & 2,23 & 1,30 & 2,26 & 0,41 & 2,09 \\
\hline & & 2016 & 3,41 & 0,68 & 3,20 & 1,52 & 1,08 & 2,25 & 0,19 & 1,76 \\
\hline & \multirow{6}{*}{ 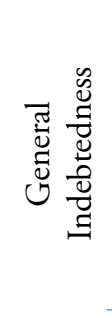 } & 2011 & $51 \%$ & $102 \%$ & $52 \%$ & $31 \%$ & $23 \%$ & $30 \%$ & $10 \%$ & $43 \%$ \\
\hline & & 2012 & $38 \%$ & $97 \%$ & $48 \%$ & $29 \%$ & $22 \%$ & $23 \%$ & $10 \%$ & $38 \%$ \\
\hline & & 2013 & $45 \%$ & $106 \%$ & $46 \%$ & $27 \%$ & $23 \%$ & $31 \%$ & $6 \%$ & $40 \%$ \\
\hline & & 2014 & $32 \%$ & $100 \%$ & $48 \%$ & $24 \%$ & - & $50 \%$ & $24 \%$ & $46 \%$ \\
\hline & & 2015 & $34 \%$ & $121 \%$ & $53 \%$ & $24 \%$ & $26 \%$ & $59 \%$ & $14 \%$ & $47 \%$ \\
\hline & & 2016 & $41 \%$ & $133 \%$ & $56 \%$ & $35 \%$ & $37 \%$ & $64 \%$ & $19 \%$ & $55 \%$ \\
\hline & \multirow{6}{*}{ 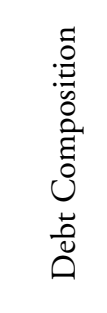 } & 2011 & $31 \%$ & $32 \%$ & $30 \%$ & $45 \%$ & $12 \%$ & $76 \%$ & $56 \%$ & $40 \%$ \\
\hline & & 2012 & $23 \%$ & $33 \%$ & $30 \%$ & $51 \%$ & $13 \%$ & $79 \%$ & $79 \%$ & $44 \%$ \\
\hline & & 2013 & $47 \%$ & $18 \%$ & $22 \%$ & $58 \%$ & $19 \%$ & $80 \%$ & $63 \%$ & $44 \%$ \\
\hline & & 2014 & $38 \%$ & $16 \%$ & $24 \%$ & $62 \%$ & - & $82 \%$ & $91 \%$ & $52 \%$ \\
\hline & & 2015 & $21 \%$ & $40 \%$ & $20 \%$ & $65 \%$ & $26 \%$ & $90 \%$ & $88 \%$ & $50 \%$ \\
\hline & & 2016 & $17 \%$ & $42 \%$ & $25 \%$ & $84 \%$ & $23 \%$ & $89 \%$ & $92 \%$ & $53 \%$ \\
\hline & \multirow{6}{*}{ 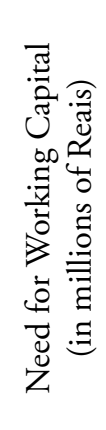 } & 2011 & -34.937 & -377.162 & -268.006 & -18.952 & -4.788 & 2.447 & 33 & -100.195 \\
\hline & & 2012 & -17.000 & -497.281 & -292.526 & -29.528 & -5.020 & 21.246 & -8.303 & -118.344 \\
\hline & & 2013 & -74.902 & -292.860 & -188.702 & -40.053 & -6.175 & 21.128 & 6.582 & -82.140 \\
\hline & & 2014 & -39.114 & -241.526 & -264.280 & -41.371 & - & 3.461 & -70.169 & -108.833 \\
\hline & & 2015 & -19.853 & -883.113 & -267.700 & -38.319 & -13.936 & -3.826 & -39.160 & -180.844 \\
\hline & & 2016 & -21.469 & -961.512 & -359.293 & -119.349 & -19.885 & -3.602 & -60.020 & -220.733 \\
\hline
\end{tabular}


BBR

17

450

Table 6

Cont.

\begin{tabular}{|c|c|c|c|c|c|c|c|c|c|c|}
\hline \multicolumn{2}{|c|}{ Indicator } & Period & CODESA & CDRJ & CODESP & CODEBA & CODERN & CDP & CDC & Average \\
\hline \multirow{30}{*}{ 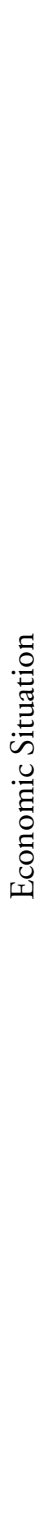 } & \multirow{6}{*}{ 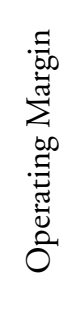 } & 2011 & $8,31 \%$ & $-27,81 \%$ & $17,57 \%$ & $-20,71 \%$ & $-169,48 \%$ & $8,66 \%$ & $2,48 \%$ & $-25,85 \%$ \\
\hline & & 2012 & $-1,43 \%$ & $-46,13 \%$ & $4,44 \%$ & $12,95 \%$ & $-212,90 \%$ & $11,22 \%$ & $0,83 \%$ & $-33,00 \%$ \\
\hline & & 2013 & $12,45 \%$ & $-44,87 \%$ & $28,24 \%$ & $9,36 \%$ & $-171,89 \%$ & $-17,88 \%$ & $-3,79 \%$ & $-26,91 \%$ \\
\hline & & 2014 & $13,21 \%$ & $-5,50 \%$ & $5,26 \%$ & $16,38 \%$ & - & $2,18 \%$ & $-87,27 \%$ & $-9,29 \%$ \\
\hline & & 2015 & $14,78 \%$ & $-147,56 \%$ & $-9,07 \%$ & $10,49 \%$ & $-249,56 \%$ & $-23,90 \%$ & $-54,35 \%$ & $-65,59 \%$ \\
\hline & & 2016 & $16,48 \%$ & $-79,21 \%$ & $-2,09 \%$ & $0,63 \%$ & $-246,22 \%$ & $-8,58 \%$ & $-67,08 \%$ & $-55,15 \%$ \\
\hline & \multirow{6}{*}{ 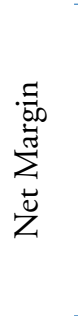 } & 2011 & $6,67 \%$ & $-48,87 \%$ & $10,41 \%$ & $-24,40 \%$ & $-153,05 \%$ & $5,98 \%$ & $2,48 \%$ & $-28,68 \%$ \\
\hline & & 2012 & $-1,43 \%$ & $-52,89 \%$ & $29,68 \%$ & $8,93 \%$ & $-187,70 \%$ & $7,96 \%$ & $0,83 \%$ & $-27,80 \%$ \\
\hline & & 2013 & $10,04 \%$ & $-44,87 \%$ & $18,76 \%$ & $6,91 \%$ & $-140,43 \%$ & $-13,06 \%$ & $-3,97 \%$ & $-23,80 \%$ \\
\hline & & 2014 & $10,99 \%$ & $-5,50 \%$ & $2,91 \%$ & $13,12 \%$ & - & $1,19 \%$ & $-87,24 \%$ & $-10,75 \%$ \\
\hline & & 2015 & $11,39 \%$ & $-147,56 \%$ & $-11,71 \%$ & $9,42 \%$ & $-249,56 \%$ & $-15,99 \%$ & $-54,35 \%$ & $-65,48 \%$ \\
\hline & & 2016 & $12,65 \%$ & $-79,21 \%$ & $-3,03 \%$ & $0,63 \%$ & $-246,22 \%$ & $-7,66 \%$ & $-67,08 \%$ & $-55,70 \%$ \\
\hline & \multirow{8}{*}{ 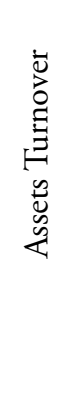 } & 2011 & 0,32 & 0,22 & 0,31 & 0,34 & 0,07 & 0,24 & 0,25 & 0,25 \\
\hline & & 2012 & 0,28 & 0,19 & 0,27 & 0,28 & 0,06 & 0,24 & 0,13 & 0,21 \\
\hline & & 2013 & 0,27 & 0,20 & 0,30 & 0,25 & 0,06 & 0,25 & 0,15 & 0,21 \\
\hline & & 2014 & 0,30 & 0,21 & 0,27 & 0,27 & - & 0,27 & 0,12 & 0,24 \\
\hline & & 2015 & 0,31 & 0,16 & 0,27 & 0,24 & 0,07 & 0,30 & 0,10 & 0,21 \\
\hline & & 2016 & 0,27 & 0,16 & 0,24 & 0,22 & 0,09 & 0,33 & 0,09 & 0,20 \\
\hline & & 2011 & $2,16 \%$ & $-10,76 \%$ & $3,23 \%$ & $-8,25 \%$ & $-10,73 \%$ & $1,46 \%$ & $0,62 \%$ & $-3,18 \%$ \\
\hline & & 2012 & $-0,40 \%$ & $-9,95 \%$ & $8,14 \%$ & $2,50 \%$ & $-10,59 \%$ & $1,94 \%$ & $0,11 \%$ & $-1,18 \%$ \\
\hline & \multirow{6}{*}{ 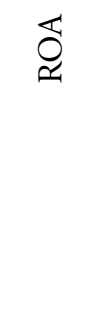 } & 2013 & $2,70 \%$ & $-8,80 \%$ & $5,57 \%$ & $1,70 \%$ & $-8,29 \%$ & $-3,21 \%$ & $-0,58 \%$ & $-1,56 \%$ \\
\hline & & 2014 & $3,26 \%$ & $-1,13 \%$ & $0,79 \%$ & $3,60 \%$ & - & $0,32 \%$ & $-10,39 \%$ & $-0,59 \%$ \\
\hline & & 2015 & $3,48 \%$ & $-23,86 \%$ & $-3,20 \%$ & $2,31 \%$ & $-18,26 \%$ & $-4,81 \%$ & $-5,17 \%$ & $-7,07 \%$ \\
\hline & & 2016 & $3,38 \%$ & $-12,46 \%$ & $-0,71 \%$ & $0,14 \%$ & $-22,65 \%$ & $-2,49 \%$ & $-6,28 \%$ & $-5,87 \%$ \\
\hline & & 2011 & $3,12 \%$ & $632,44 \%$ & $6,73 \%$ & $-16,92 \%$ & $-14,00 \%$ & $1,64 \%$ & $0,70 \%$ & $87,67 \%$ \\
\hline & & 2012 & $-0,56 \%$ & $-387,02 \%$ & $15,57 \%$ & $4,02 \%$ & $-13,63 \%$ & $2,21 \%$ & $0,12 \%$ & $-54,18 \%$ \\
\hline & \multirow{4}{*}{ 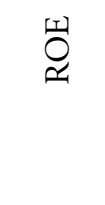 } & 2013 & $3,73 \%$ & $153,69 \%$ & $10,25 \%$ & $3,07 \%$ & $-10,72 \%$ & $-3,81 \%$ & $-0,62 \%$ & $22,23 \%$ \\
\hline & & 2014 & $4,31 \%$ & $309,06 \%$ & $1,52 \%$ & $5,32 \%$ & - & $0,38 \%$ & $-13,70 \%$ & $51,15 \%$ \\
\hline & & 2015 & $4,57 \%$ & $111,62 \%$ & $-6,79 \%$ & $3,48 \%$ & $-24,52 \%$ & $-5,76 \%$ & $-5,98 \%$ & $10,95 \%$ \\
\hline & & 2016 & $5,21 \%$ & $38,06 \%$ & $-1,63 \%$ & $0,23 \%$ & $-35,81 \%$ & $-3,00 \%$ & $-7,76 \%$ & $-0,67 \%$ \\
\hline
\end{tabular}

Source: Elaborated by the authors.

CODESP presented a low current ratio on the deficient level and below the sector's average, although general liquidity was high with levels between good and great. This is due to the high volume of long-term receivable accounts and the existence of a high volume of deferred taxes, which, on average, represent $38 \%$ of the total asset volume. In rentability terms, we found a reduction in the value indicators and high volatility, going from positive margins and rentability in the beginning of the period analyzed, to negative values by the end of the period. Nevertheless, in line with the previous port authorities, we found excessive financial resources used for application.

The financial situation of CODEBA presented decreasing liquidity during the analyzed period, while still maintaining good to great levels, above the port authorities' average. Still, we highlight the low indebtedness, with a focus on short-term debts, but also characterized by 
financial resources intended to increase in capital and the share of complementary welfare. In contrast with the findings from the other port authorities, CODEBA presented better results on rentability aspects, which indicates an operation that has great value-generation capability.

CODERN presented a sound financial situation, with a surplus of financial resources, as indicated by the negative need for working capital, and liquidity at good levels, in spite of a decrease in the index. In rentability terms, the situation assessed by the standard index is considered terrible, with negative margins and rentability, which calls for a critical vision of the operational processes of this port authority.

We found a decrease in CDP's current ratio, caused by the increase in the short-term indebtment of the company. The increase in the company's debt seems to have occurred because of the lack of working capital observed in the period between 2011 and 2014. The margins presented high volatility ranging from highly negative to highly positive values, accompanied by the rentability which, in addition to being low when positive, it also showed negative returns.

Finally, the Companhia Docas do Ceará (CDC) presented decreasing liquidity, nevertheless, we found low levels of indebtedness and a need to control the working capital, which presented a balance over the period analyzed. Regarding the rentability, we found a decreasing tendency, presenting negative margins and rentability rates.

In current ratio terms, we found that CODESA and CODEBA present the best situation in relation to the other port authorities, and they also show a good indebtedness situation. It is important to highlight that CODEBA's greatest indebtedness is the short-term type, which may compromise its financial situation. CDC is the organization with the lowest indebtedness, nevertheless, most of it was also short-term. CDRJ is the port authority with the least liquidity and the highest indebtedness rate. Additionally, the organization also presented the highest level of resource surplus represented by the need for working capital.

In sum, analyzing the traditional indicators, we found port authorities tend to present good financial situation. Liquidity and indebtedness were found to be balanced and with surplus of applied resources which indicates solvency conditions. This is indicated by the good liquidity and negative need for working capital (Matarazzo, 2010; Monteiro, 2003; Santos \& Francisco, 2016).

This is due to the structure of the capital invested in the organization, since port authorities count with third-party non-onerous capital, corresponding to the capital investments made by the Federal Government through covenants and/or other bonds which do not present characteristics of capital addition to the shareholders' equity (Alves \& Silva, 2015; Corrêa \& Melo, 2012). Thus, findings from the financial information available show that investments in fixed assets, as well as big works as dredging, are financed by the capital contributed by the Federal Government.

It is important to highlight that, given the characteristics of their activities, ports are developments with major investments in fixed assets. We highlight that the group of assets analyzed here (i.e. fixed assets) is composed of elements without monetary correction; therefore, these assets can be outdated, which demands greater attention while analyzing and making comparisons (Martins et al., 2012). Nevertheless, the financial analysis shows high levels of fixed shareholders' equity, which denotes that port authorities apply almost all of their equity resources in these assets. Financially, this situation can draw attention since it reduces the share of equity working capital (which presents long-term demandability characteristics) and could be invested in working assets to enable greater financial autonomy to the organization, reducing the dependency on thirdparty capital (Matarazzo, 2010).

Contrarily to the findings from the financial assessment, findings from the economic situation of the ports analyzed show an uncomfortable situation. Our results show insufficient (negative) 
BBR

17

452

profit margins and, when such margins are positive, the values seem to be poorly attractive to investors. Analyzing the return on assets and the return on equity, results are not satisfactory.

Table 7 presents the variables used for the EVA calculation, as well as the average economic value of the port authorities for the period of 2011 to 2016. Table 8, on the other hand, presents the EVA values for the port authorities and their evolution for the period under analysis.

Table 7

Variables and average Economic Value Added (EVA) of the port authorities between 2011 and 2016

\begin{tabular}{lccccccc}
\hline Indicators & CODESA & CDRJ & CODESP & CODEBA & CODERN & CDP & CDC \\
\hline NOPAT (R $\$)$ & 4.524 & 30 & 33.475 & 9.840 & -6.967 & -5.958 & -7.573 \\
Invested & 259.305 & 259.305 & 1.521 .023 & 275.452 & 276.580 & 366.920 & 251.361 \\
Capital & $9,44 \%$ & $9,28 \%$ & $9,44 \%$ & $9,44 \%$ & $9,08 \%$ & $9,44 \%$ & $9,44 \%$ \\
Cost of Debt & $15,06 \%$ & $15,06 \%$ & $15,44 \%$ & $15,02 \%$ & $15,06 \%$ & $15,12 \%$ & $15,03 \%$ \\
CAPM & $10,04 \%$ & $10,04 \%$ & $10,45 \%$ & $10,07 \%$ & $9,86 \%$ & $10,02 \%$ & $10,06 \%$ \\
WACC & -21.532 & -38.865 & -128.972 & -31.773 & -84.898 & -61.234 & -46.326 \\
\hline EVA & & & & & & &
\end{tabular}

Source: Elaborated by the authors.

As observed, CODESA presented an EVA in a less unfavorable situation in comparison to the other port authorities, besides presenting fewer variations over the period analyzed. When analyzed together with the traditional indicators, CODESA also presents the best rentability rates compared to other port authorities, both in profit margins and in rentability of the invested capital.

Table 8

Evolution of the Economic Value Added between 2011 and 2016

\begin{tabular}{|c|c|c|c|c|c|c|c|}
\hline & CODESA & CDRJ & CODESP & CODEBA & CODERN & CDP & $\mathrm{CDC}$ \\
\hline & \multicolumn{7}{|c|}{ EVA (in millions of Reais) } \\
\hline 2011 & -20.197 & -15.173 & -16.591 & -14.562 & -48.378 & -34.545 & -11.327 \\
\hline 2012 & -13.227 & -33.527 & -117.482 & -32.915 & -85.216 & -52.128 & -35.383 \\
\hline 2013 & -34.095 & -55.375 & -160.984 & -53.572 & -127.548 & -104.909 & -70.586 \\
\hline 2014 & -18.967 & -45.439 & -133.165 & -34.787 & - & -59.967 & -62.135 \\
\hline 2015 & -8.729 & -31.972 & -115.139 & -18.833 & -71.880 & -54.476 & -40.206 \\
\hline 2016 & -33.979 & -51.706 & -230.468 & -35.969 & -91.470 & -61.381 & -58.316 \\
\hline Average & -21.532 & -38.865 & -128.972 & -31.773 & -84.898 & -61.234 & -46.326 \\
\hline
\end{tabular}

Source: Elaborated by the authors.

Still, regarding rentability, we found that CODEBA also presents a less uncomfortable situation, with positive margins and rentability for the capital invested. In spite of presenting a negative economic value, when compared to the other port authorities, CODEBA is in better economic situation, only behind CODESA.

In sum, the EVA indicators present a destruction of the economic value, which corroborates the results found by Alves and Silva (2015). Similarly to the findings of Alves and Silva (2015), the indicators present an environment of high opportunity costs (WACC), low return on investments, and the destruction of the economic value. This scenario is translated into the low 
attractiveness of port activities to private capital, since they reveal a great difficulty in remunerating the invested capital.

In addition, these economic aspects can influence the financial sustainability of the ports. The low economic results of the port system may reduce the interest of investors, consequently reducing the potential economic growth of the sector and the region. It can be explained by the importance level of the economic indicators associated with the employment generation found in South Korea's port sustainability assessment, which seems to supported by the fact that it is a development economy (Oh, Lee, \& Seo, 2018), similar to the Brazilian environment.

This scenario suggests the need to optimize both economic and financial management, balancing the economic regimen and public policy, enabling greater management autonomy for port authorities and for self-funding, which would reduce the need for governmental contributions. Port management models based on the economic optics have been applied in the Spanish port system (Lunkes, Ripoll-Feliu, Giner-Fillol, \& da Rosa, 2013), as well as in Greek ports (Pallis \& Syriopoulos, 2007).

De Langen and Van der Lugt (2017) argue that, it is appropriate to regard the port authority as a port development company, once the port development is intrinsically commercial. According to authors, an institutional reforms in the port authorities in the Netherlands, has lead to corporatization of the port authorities. As result, all port authorities have shown financial performance improving.

The economic situation we found presents the opportunity for the development of a system for costs strategic management with the aim to assess the economic viability of port operations that lead to the improvement of port management. Lunkes et al. (2013) highlight that improvements in port management also benefit society, since gains in competitiveness also reflect on other economic sectors and areas influenced by ports.

\section{CONCLUSIONS}

This study aimed to investigate the results of the economic and financial management of Brazilian public ports by assessing the economic value addition capacity. To that end, the economic and financial dimensions were analyzed through traditional indicators and through the EVA which is grounded on the value-based management.

Since ports play important roles in the international logistic chain and in the local economic development, great attention from the Federal Government is expected in port management, seeking greater organizational performance and market competitiveness. Nevertheless, our findings show the opposite: low investment and inefficient infrastructure that compromises the sector's competitiveness.

This study showed that little attention is given to the port sector's economic and financial management. We found a favorable liquidity situation, nevertheless, this was not due to the financial results of the businesses' operations, rather, it was due to Federal Government's continuous investments. This is observed in the negative economic value added which indicates that the normal operation of the port venture is not capable of generating sufficient rentability to financially maintain the operation and to remunerate the capital invested. In other words, the Brazilian ports' present a value destruction situation and, therefore, they are not attractive to private investments.

This continuous result indicates the incapacity of business financial sustainability, requiring incessant Federal Governmental subsidy to keep ports operating. In the face of the Federal Government's distancing from the port operations in order to become the port space manager, 
such financial movement tends to benefit port operators that use the terminals without leasing them, exempting them from the need to make capital investments.

Thus, the study sought to contribute to the discussion about Brazilian public management of the port sector, its performance and competitivity, as well as to how public resources invested in the ports are managed. In this sense, we highlight that port authorities, as public companies, may have other goals that go beyond generating profitability. They are responsible for port planning and strategy, as well as being a government instrument for public policy (Rattner, 1984). However, the results shed light on the discussion of port reforms, which, in Europe, resulted in improved port performance, also in financial and investment terms (de Langen \& van der Lugt, 2017; Panayides, Lambertides, \& Andreou, 2017).

We highlight that the research was limited to the assessment of the port authorities of the direct administration, that is, the "Companhia Docas" companies, since they publicly release their accounting statements under the accounting legislation for publicly traded organizations. Therefore, public ports under the administration of Municipalities or States were not analyzed given that their accounting statements follow the regulations of public accountancy. We also highlight that we limited the study to a financial analysis, therefore strategic importance of the port sector and its role as an instrument of governmental policy were not considered.

Future studies can extend the research to ports in which the Federal Government transferred the administrative responsibility to other governmental levels, thus studies can assess the financial and economic indicators based on accounting statements that follow public accountancy regulations, by comparing these two organizational groups of the Brazilian port sector. Additionally, studies can propose cost strategic management models for ports.

\section{REFERENCES}

Aguiar, A. B. d., Pimentel, R. C., Rezende, A. J., \& Corrar, L. J. (2007). Criação de valor para o acionista: uma análise dos direcionadores de valor em empresas brasileiras. Paper presented at the XXXI ENANPAD, Rio de Janeiro.

Alves, A. d. S., \& Silva, J. G. S. L. d. (2015). Gestão Portuária no Brasil: criação ou destruição de valor? Gestão \& Regionalidade, 31(93), 109-126. https://dx.org/10.13037/gr.vol31n93.2732

ANTAQ. (2007). Nota Técnica $n^{o} 17$. Superintendência de Portos Gerência de Portos Públicos Retrieved from www.antaq.gov.br/portal/GestaoPortuaria/pdf/ModelagemArrendamento.pdf.

ANTAQ. (2009). Nota Técnica no 25/2009 - GPP - A. Brasília - DF. http://web.antaq.gov.br/portal/ audienciapublica/2016_03/pdf/aud032016/aud032016_nota_tecnica_09_2016.pdf.

Araújo, A. M. P. d., \& Assaf Neto, A. (2003). A contabilidade tradicional e a contabilidade baseada em valor. Revista Contabilidade \& Finanças, 14(33), 16-32. https://dx.doi.org/10.1590/S151970772003000300002

Bandara, Y. M., \& Nguyen, H.-O. (2016). Influential factors in port infrastructure tariff formulation, implementation and revision. Transportation Research Part A: Policy and Practice, 85, 220-232.

Bank, W. (2001). Alternative port management structures and ownership models. http://www.ppiaf.org/ sites/ppiaf.org/files/documents/toolkits/portoolkit/toolkit/pdf/modules/03_toolkit_module3.pdf

Beuren, M. M., Andriotti, R., Vieira, G. B. B., Ribeiro, J. L. D., \& Neto, F. J. K. (2018). On measuring the efficiency of Brazilian ports and their management models. Maritime Economics \& Logistics, 20(1), 149-168. 
Bottasso, A., Conti, M., Ferrari, C., \& Tei, A. (2014). Ports and regional development: a spatial analysis on a panel of European regions. Transportation Research Part A: Policy and Practice, 65, 44-55.

Brandão, L. E. T., Bastian-Pinto, C. d. L., Gomes, L. L., \& Salgado, M. S. (2012). Incentivos governamentais em PPP: uma análise por opçôes reais. RAE-Revista de Administração de Empresas, 52(1), 010-023.

Brasil. (1967). Decreto-Lei no 200, de 25 de fevereiro de 1967. Brasilia: Diário Oficial da União.

Brasil. (1988). Constituição da República Federativa do Brasil.

Brasil. (2016). Lei no 13.341, de 29 de setembro de 2016. Brasilia: Diário Oficial da União.

Brasil. (2017). Decreto no 9.000, de 8 de Março de 2017. Brasilia: Diário Oficial da União.

Brigham, E. F., Gapenski, L. C., \& Ehrhardt, M. C. (2001). Administração financeira: teoria e prática (A. L. G. Alcântara \& J. N. A. Salazar, Trans.). São Paulo: Atlas.

Britto, P. A. P. d., Coutinho, P. C., Carvalho, A. X. Y. d., Oliveira, A. L. R. d., Lustosa, P. R. B., Albuquerque, P. H. M. (2015). Promoção da concorrência no setor portuário: uma análise a partir dos modelos mundiais e aplicação ao caso brasileiro. Revista de Administração Pública-RAP, 49(1), 47-71. https://dx.doi.org/10.1590/0034-76121690

Bruni, A. L., \& Famá, R. (2003). As decisóes de investimentos (3 ed. Vol. 2). São Paulo: Atlas.

Chang, Y.-T., Shin, S.-H., \& Lee, P. T.-W. (2014). Economic impact of port sectors on South African economy: An input-output analysis. Transport Policy, 35, 333-340. https://dx.doi.org/10.1016/j. tranpol.2014.04.006

Corrêa, M. C., \& Melo, A. A. d. O. (2012). Gestão financeira de empresas públicas de economia mista municipal-uma aplicação do Modelo Dinâmico. Revista Brasileira de Contabilidade, 173, 64-77.

de Langen, P. W., \& van der Lugt, L. M. (2017). Institutional reforms of port authorities in the Netherlands; the establishment of port development companies. Research in Transportation Business \& Management, 22, 108-113.

Fageda, X., \& Gonzalez-Aregall, M. (2014). Port charges in Spain: the roles of regulation and market forces. International Journal of Shipping and Transport Logistics, 6(2), 152-171. https://dx.doi. org/10.1504/ijstl.2014.059568

Fernandes, V. (2016). Os desafios do Antitruste no Setor Portuário Brasileiro: as inovaçóes da Lei no 12.815/13 e seus reflexos concorrenciais. Journal of Law and Regulation, 2(1), 161-210.

GEIPOT. (2001). A reforma portuária brasileira M. d. Transportes (Ed.) Empresa Brasileira de Planejamento de Transportes

Girão, L. F. d. A. P., Machado, M. A. V., \& Callado, A. L. C. (2013). Análise dos Fatores que Impactam o MVA das Companhias Abertas Brasileiras: Será o EVA ${ }^{\oplus}$ mais Value Relevant que os Indicadores de Desempenho Tradicionais? Sociedade, Contabilidade e Gestão, 8(2), 89-105.

Gomes, C. F. S., Dos Santos, J. P. C., \& Costa, H. G. (2013). Eficiência Operacional dos Portos Brasileiros: Fatores Relevantes. Sistemas \& Gestão, 8(2), 118-128. https://dx.doi.org/10.7177/ sg.2013.v8.n2.a2

Ignasiak-Szulc, A., Juscius, V., \& Bogatova, J. (2018). Economic Evaluation Model of Seaports' Performance Outlining Competitive Advantages and Disadvantages. Engineering Economics, 29(5), 571-579. https://dx.doi.org/10.5755/j01.ee.29.5.21363 
BBR

17

456

Kim, W. G. (2006). EVA and traditional accounting measures: Which metric is a better predictor of market value of hospitality companies? Journal of Hospitality \& Tourism Research, 30(1), 34-49. https://dx.doi.org/10.1177/1096348005284268

Kitzberger, H., \& Padoveze, C. L. (2004). Integração do Modelo Fleuriet com a Abordagem Tradicional de Análise das Demonstraçóes Contábeis. Pensar Contábil, 6(23), 14-20.

Lee, S., \& Kim, W. G. (2009). EVA, refined EVA, MVA, or traditional performance measures for the hospitality industry? International Journal of Hospitality Management, 28(3), 439-445. https:// dx.doi.org/10.1016/j.ijhm.2009.01.004

Lunkes, R. J., Ripoll-Feliu, V., Giner-Fillol, A., \& da Rosa, F. S. (2013). Estudo sobre a implantação do orçamento baseado em desempenho na Autoridade Portuária de Valência. Revista de Administração Pública FGV, 47(1), 49-76.

Martins, E. (2012). Avaliação de empresas: da mensuração contábil à econômica. São Paulo: Atlas.

Martins, E., Diniz, J. A., \& Miranda, G. J. (2012). Análise avançada das demonstraçóes contábeis: uma abordagem crítica. São Paulo: Atlas.

Matarazzo, D. C. (2010). Análise Financeira de Balanços - Abordagem Gerencial (7th ed.). São Paulo: Atlas.

Milan, G. S., Vieira, G. B. B., \& Gonçalves, R. B. (2014). Análise da Eficiência Portuária da Região Sul do Brasil. Paper presented at the Simpósio de Administração da Produção, Logística e Operaçóes Internacionais, Sáo Paulo - SP.

Monteiro, A. A. S. (2003). Fluxos de caixa e capital de giro: uma adaptação do modelo de Fleuriet. Pensar Contábil, 6(20), 27-33.

Neto, A. A. (2012). Finanças corporativas e valor (6. ed ed.). São Paulo: Atlas.

Neto, A. A., Araújo, A. M. P. d., \& Fregonesi, M. S. F. d. A. (2006). Gestão baseada em valor aplicada ao terceiro setor. Revista Contabilidade \& Finanças, 17(spe), 105-118. https://dx.doi.org/10.1590/ S1519-70772006000400009

Neto, A. A., Lima, F. G., \& Araújo, A. M. P. d. (2008). Uma proposta metodológica para o cálculo do custo de capital no Brasil. Revista de Administração, 43(1), 72-83.

Nguyen, H.-O., Nghiem, H.-S., \& Chang, Y.-T. (2018). A regional perspective of port performance using metafrontier analysis: the case study of Vietnamese ports. Maritime Economics \& Logistics, 20(1), 112-130.

Notteboom, T. E. (2008). The relationship between seaports and the inter-modal hinterland in light of global supply chains. In European challenges OECD - International Transport Forum. Paris. Discussion Paper No. 2008-10.

Oh, H., Lee, S.-W., \& Seo, Y.-J. (2018). The evaluation of seaport sustainability: the case of South Korea. Ocean \& Coastal Management, 161, 50-56. https://dx.doi.org/10.1016/j.ocecoaman.2018.04.028

Pallis, A. A., \& Syriopoulos, T. (2007). Port governance models: financial evaluation of Greek port restructuring. Transport Policy, 14(3), 232-246. https://dx.doi.org/10.1016/j.tranpol.2007.03.002

Panayides, P. M., Lambertides, N., \& Andreou, C. (2017). Reforming public port authorities through multiple concession agreements: The case of Cyprus. Research in Transportation Business \& Management, 22, 58-66. 
Pires, G. C. (2017). Análise da Eficiência Portuária usando a Metodologia da Análise Envoltória de Dados (DEA). Revista Eletrônica de Estratégia \& Negócios, 10, 55-79. https://dx.doi.org/10.19177/ reen.v10e0201755-79

Rattner, H. (1984). As empresas estatais brasileiras e o desenvolvimento tecnológico nacional. Revista de Administração de Empresas, 24(2), 5-12.

Rocha, C. H., Britto, P. A. P., \& Uderman, S. (2016). Abertura de capital e Governança Corporativa no setor portuário brasileiro. RGC-Revista de Governança Corporativa, 3(1), p.72-95. https:// dx.doi.org/10.21434/rgc.v6i1.74

Salazar, G. T. (2012). Administração dos fluxos de caixa: teoria e prática. São Paulo: Atlas.

Santos, G. T., \& Francisco, J. R. d. S. (2016). Indicadores de Liquidez Versus Modelo Dinâmico: Aplicaçáo no Período Pré e Pós-Crise no Segmento Bancos. Revista de Contabilidade e Controladoria, 8(2), 8-22. https://dx.doi.org/10.5380/rcc.v8i2.37471

Sharma, A. K., \& Kumar, S. (2010). Economic value added (EVA)-literature review and relevant issues. International Journal of Economics and Finance, 2(2), 200-220. https://dx.doi.org/10.5539/ ijef.v2n2p200

Silva, R. N. S. d., \& Vieira, T. d. A. B. (2010). Integrated ABC-EVA system as a management tool: a case study. BBR - Brazilian Business Review, 7(1), 089-110. https://dx.doi.org/10.15728/ bbr.2010.7.1.5

Sousa, E. F. d., \& Galdi, F. C. (2016). The relationship between equity ownership concentration and earnings quality: evidence from Brazil. Revista de Administração, 51(4), 331-343. https://dx.doi. org/10.1016/j.rausp.2016.07.006

Taffarel, M., Silva, W. V. d., \& Clemente, A. (2013). Risco regulatório e reação do mercado: análise do setor de energia elétrica brasileiro. Revista Universo Contábil, 9(1), 121-134. https://dx.doi. org/10.4270/ruc. 2013107

Tan, Q.-m., Zhang, N., \& Ma, M.-z. (2011). Empirical investigation on EVA and accounting performance measures: Evidence from China stock market. Paper presented at the Industrial Engineering and Engineering Management (IE\&EM), 2011 IEEE 18Th International Conference on.

Tovar, A. C. d. A., \& Ferreira, G. C. M. (2006). A infra-estrutura portuária brasileira: o modelo atual e perspectivas para seu desenvolvimento sustentado. Revista do BNDES, 13(25), 209-230.

Tutino, M. (2011). Which metrics are relevant in european listed companies? Evidence from nineties. Corporate Ownership \& Control, 8(2), 566-588.

Uderman, S., Rocha, C. H., \& Cavalcante, L. R. (2012). Modernização do sistema portuário no Brasil: uma proposta metodológica. Journal of Transport Literature, 6(1), 221-240. https://dx.doi. org/10.1590/S2238-10312012000100014

Vaggelas, G. K. (2019). Measurement of port performance from users' perspective. Maritime Business Review, 4(2), 130-150. https://dx.doi.org/10.1108/mabr-08-2018-0024

Vieira, G. B. B., Milan, G. S., Kliemann Neto, F. J., Rodrigues, S. L. A., \& Ramos, F. F. N. (2011). $A$ ções de governança em clusters portuários: a proposição de um modelo conceitual no contexto do porto de buenos aires. Paper presented at the XXXI Encontro Nacional de Engenharia de Produção, Belo Horizonte - MG. 